\begin{abstract}
ABNORMAL levels of pulmonary eicosanoids have been reported in infants with persistent pulmonary hypertension (PPH) and congenital diaphragmatic hernia $(\mathrm{CDH})$. We hypothesized that a dysbalance of vasoconstrictive and vasodilatory eicosanoids is involved in $\mathrm{PPH}$ in $\mathrm{CDH}$ patients. The levels of several eicosanoids in lung homogenates and in bronchoalveolar lavage fluid of controls and rats with $\mathrm{CDH}$ were measured after caesarean section or spontaneous birth. In controls the concentration of the stable metabolite of prostacyclin (6-keto-PGF $1 \alpha$ ), thromboxane $A_{2}$ $\left(\mathrm{Tx}_{\mathbf{2}}\right)$, prostaglandin $\mathrm{E}_{2}\left(\mathrm{PGE}_{2}\right)$, and leukotriene $\mathrm{B}_{4}\left(\mathrm{LTB}_{4}\right)$ decreased after spontaneous birth. $\mathrm{CDH}$ pups showed respiratory insufficiency directly after birth. Their lungs had higher levels of 6 keto-PGF $F_{1 \alpha}$, reflecting the pulmonary vasodilator prostacyclin $\left(\mathrm{PGI}_{2}\right)$, than those of controls. We conclude that in $\mathrm{CDH}$ abnormal lung eicosanoid levels are present perinatally. The elevated levels of 6-keto-PGF $1 \alpha$ in $\mathrm{CDH}$ may reflect a compensation mechanism for increased vascular resistance.
\end{abstract}

Key words: Diaphragmatic hernia, Leukotrienes, Lung, Newborn animals, Prostaglandins, Pulmonary hypertension, Thromboxanes

\section{Lung eicosanoids in perinatal rats with congenital diaphragmatic hernia}

\author{
H. IJsselstijn, ${ }^{1,2}$ F. J. Zijlstra, ${ }^{3}$ J. P. M. van Dijk, ${ }^{3}$ \\ J. C. de Jongste ${ }^{2}$ and D. Tibboel ${ }^{1, C A}$
}

Departments of ${ }^{1}$ Paediatric Surgery, ${ }^{2}$ Paediatrics, Division of Respiratory Medicine, ${ }^{3}$ Pharmacology, Erasmus University Rotterdam and University Hospital/Sophia Children's Hospital,

Dr. Molewaterplein 60, 3015 GJ Rotterdam,

The Netherlands

${ }^{\mathrm{CA}}$ Corresponding Author

Tel: $(+31) 104636567$

Fax: $(+31) 104636288$

\section{Introduction}

Eicosanoids are arachidonic acid metabolites which are produced in different tissues in human and animal species. ${ }^{1}$ They have been studied extensively in relation to the perinatal pulmonary circulation, and have been implicated in several physiologic and pathologic conditions such as persistent pulmonary hypertension (PPH). ${ }^{2-7}$

Prostacyclin $\left(\mathrm{PGI}_{2}\right)$, prostaglandin $\mathrm{E}_{2}\left(\mathrm{PGE}_{2}\right)$, and thromboxane $\mathrm{A}_{2}\left(\mathrm{TxA}_{2}\right)$ are all generated via the cyclooxygenase pathway; the latter has a pulmonary vasoconstricting activity, whereas the other two are pulmonary vasodilators. ${ }^{6}$ Increased circulating levels of $\mathrm{PGE}_{2}$ may contribute to the pathogenesis of patent ductus arteriosus. ${ }^{8}$ Leukotrienes, which are formed by the 5-lipoxygenase pathway, may have a key function in maintaining the elevated pulmonary vascular resistance in the fetus, ${ }^{6,9}$ although this could not be confirmed in other studies. 70

Children with congenital diaphragmatic hernia $(\mathrm{CDH})$ have abnormal morphological development of lungs and intrapulmonary blood vessels. ${ }^{11,12}$ The high neonatal mortality and morbidity is ascribed to the extent of lung hypoplasia and $\mathrm{PPH}^{13}$ Increased levels of leukotrienes, and of metabolites of $\mathrm{PGI}_{2}$ and $\mathrm{Tx}_{2}$ have been reported in plasma and in bronchoalveolar lavage (BAL) fluid of both PPH patients without $\mathrm{CDH}$ and children with $\mathrm{CDH}^{14-21}$

We hypothesized that the pulmonary vascular abnormalities in $\mathrm{CDH}$ cause abnormal transition of the pulmonary circulation at birth, associated with a dysbalance of vasoconstrictive and vasodilatory eicosanoids. Therefore, we studied the content of different eicosanoids-metabolites from the cyclooxygenase and one from the lipoxygenase pathway - in lung homogenates and in BAL fluid of perinatal rats with $\mathrm{CDH}^{22}$ The pulmonary vascular abnormalities in these rat pups strongly resemble those of children with $\mathrm{CDH}^{23}$

\section{Materials and Methods}

Animal model

Female Sprague-Dawley rats (Harlan Olac, UK) were mated during $1 \mathrm{~h}$ (day 0 of gestation). Nine of 18 pregnant rats received $100 \mathrm{mg}$ of 2,4-dichloro-phenyl-p-nitrophenylether (Nitrofen: Rohm Has Company, Philadelphia, PA) in $1 \mathrm{ml}$ of olive oil orogastrically under light ether anaesthesia on day 10 of gestation, ${ }^{22}$ the remaining nine rats provided control pups. Nitrofen induces a large left-sided diaphragmatic defect 
with severe lung hypoplasia in up to $80 \%$ of the offspring using this regimen. ${ }^{22}$ Food and water were supplied ad libitum during the whole period of pregnancy. Nine pregnant dams were anaesthetized by inhalation of diethylether and a caesarean section was performed on day 22 (nitrofen-exposed litters $n=5$; control litters $n=4)$. While they were kept in the membranes to prevent any breathing, the fetuses died after cervical intersection with a needle, and were weighed. Only rat pups that could be processed within the first $30 \mathrm{~min}$ of anaesthesia were included. In the remaining litters (nitrofenexposed $n=4$, and controls $n=5$ ) spontaneous birth on day $22-23$ was awaited; within 5-10 min after birth they were killed as described above, and weighed. The presence of a diaphragmatic defect in all nitrofen-exposed rat pups was revealed by autopsy. To obtain a homogeneous group only nitrofen-exposed rat pups with left-sided or bilateral diaphragmatic defects with concomitant severe lung hypoplasia were included, and nitrofen-exposed pups with small right-sided defects or without $\mathrm{CDH}$ were excluded. Thus four different groups were studied: $\mathrm{CDH}$ rat pups after caesarean section or born spontaneously, and control pups after caesarean section or born spontaneously. Either BAL procedure or dissection of the lungs for preparation of homogenates was then performed.

\section{Lung homogenates}

The lungs were removed, stripped of nonpulmonary tissue, separated, weighed, frozen in liquid $\mathrm{N}_{2}$, and stored at $-70^{\circ} \mathrm{C}$ until further processed. They they were homogenized in $1 \mathrm{ml}$ in Krebs-solution, and centrifuged at $2500 \mathrm{~g}$. The content of eicosanoids and protein was measured in the supernatant. Ten samples were obtained in $\mathrm{CDH}$ pups after caesarean section and four in spontaneously born pups. In controls the numbers were $n=11$ and $n=23$, respectively.

\section{BAL procedure}

After opening of the abdominal cavity and assessment of the diaphragmatic defect in the nitrofen-exposed pups, the thorax was opened, and a tracheotomy was performed. A polyethylene catheter (Portex, UK; outer diameter $0.61 \mathrm{~mm}$ or $1.0 \mathrm{~mm}$, inner diameter 0.28 or $0.5 \mathrm{~mm}$, for $\mathrm{CDH}$ pups and controls respectively) was inserted into the trachea and ligated. A 1 ml-syringe with $\mathrm{NaCl} 0.9 \%$ heated to $37^{\circ} \mathrm{C}$, was connected to the catheter, and the lungs were washed as previously described.$^{24}$ In $\mathrm{CDH}$ pups the lungs were washed with seven to 10 times 0.05 to $0.1 \mathrm{ml}$. Lungs from control pups were washed four times with 0.25 to $0.45 \mathrm{ml}$, until $1 \mathrm{ml}$ of fluid had been recovered. Samples that were visibly contaminated with blood were excluded. Ten samples were obtained in each $\mathrm{CDH}$ group, and 13 samples in each control group. The BAL fluid was directly frozen in liquid $\mathrm{N}_{2}$ and stored at $-70^{\circ} \mathrm{C}$ until assay.

\section{Measurement of eicosanoids and total protein}

The following eicosanoids were measured by radioimmunoassay: 6keto- $\mathrm{PGF}_{1 \alpha}$ (the stable metabolite of prostacyclin), $\mathrm{PGE}_{2}, \mathrm{Tx}_{2}$ (the stable metabolite of $\mathrm{TxA}_{2}$ ), all three generated by the cyclooxygenase pathway, and leukotriene $\mathrm{B}_{4}$ $\left(\mathrm{LTB}_{4}\right)$, a lipoxygenase-derived metabolite of arachidonic acid. All assays were performed as described in detail previously. ${ }^{25}$ Total protein was measured by ELISA at $595 \mathrm{~nm}$ using a commercially available protein reagent and protein standard (Instruchemie B.V., Hilversum, the Netherlands).

\section{Data analysis}

All eicosanoid levels are expressed as $\mathrm{pg} / \mu \mathrm{g}$ protein (mean \pm SEM), unless stated otherwise. Differences between groups were tested by Student's $t$-test or by the non-parametric MannWhitney test if appropriate. Statistical significance was assumed at 5\%level.

\section{Results}

All spontaneously born control pups had a regular respiration rate and were pink within minutes after birth. Respiratory insufficiency with gasping and cyanosis was observed in rat pups with $\mathrm{CDH}$, but not in controls, directly after birth.

The lung weights in spontaneously born control pups were significantly lower than those in controls delivered by caesarean section (Table $1 ; P<0.001$ ). This was not the case in the $\mathrm{CDH}$ pups: the lung weights were similar in both groups (Table 1). Control lungs were significantly heavier than lungs in $\mathrm{CDH}(P<$ $0.001)$.

\section{Results in lung homogenates}

First, data from the left and the right lungs in all groups were analysed separately to determine whether there were consistent differences in 
Table 1. Lung weights and total amount of eicosanoids in lung homogenates of controls and $\mathrm{CDH}$ pups after delivery by caesarean section or after spontaneous birth

\begin{tabular}{|c|c|c|c|}
\hline & & Caesarean section & Spontaneous birth \\
\hline Lung weight (mg) & $\begin{array}{l}\text { Control } \\
\mathrm{CDH}\end{array}$ & $\begin{aligned} 149 & \pm 2 \\
62 & \pm 2^{a}\end{aligned}$ & $\begin{array}{r}115 \pm 4^{\mathrm{b}} \\
62 \pm 3^{\mathrm{a}}\end{array}$ \\
\hline 6-keto-PGF $1 \alpha$ (pg) & $\begin{array}{l}\text { Control } \\
\mathrm{CDH}\end{array}$ & $\begin{array}{l}4340 \pm 210 \\
7830 \pm 320^{a}\end{array}$ & $\begin{array}{l}3260 \pm 160^{b} \\
7670 \pm 270^{a}\end{array}$ \\
\hline $\mathrm{TxB}_{2}(\mathrm{pg})$ & $\begin{array}{l}\text { Control } \\
\mathrm{CDH}\end{array}$ & $\begin{array}{l}27620 \pm 1600 \\
21070 \pm 1320^{a}\end{array}$ & $\begin{array}{l}21560 \pm 850^{b} \\
19970 \pm 880\end{array}$ \\
\hline $\mathrm{PGE}_{2}(\mathrm{pg})$ & $\begin{array}{l}\text { Control } \\
\mathrm{CDH}\end{array}$ & $\begin{array}{l}42110 \pm 2210 \\
27750+2050^{a}\end{array}$ & $\begin{array}{l}30410 \pm 1450^{b} \\
24690+1630^{a}\end{array}$ \\
\hline $\mathrm{LTB}_{4}(\mathrm{pg})$ & $\begin{array}{l}\text { Control } \\
\mathrm{CDH}\end{array}$ & $\begin{array}{l}3410 \pm 180 \\
2160 \pm 150^{\mathrm{a}}\end{array}$ & $\begin{array}{l}2950 \pm 130^{b} \\
2610 \pm 350\end{array}$ \\
\hline
\end{tabular}

All data are expressed as mean \pm SEM. The numbers per group are: $n=11$ and $n=23$ for the controls delivered by caesarean section and by spontaneous birth, respectively; $n=10$ and $n=4$ for the respective $\mathrm{CDH}$ groups.

aSignificantly different from control, same delivery mode; $\mathrm{P}<0.05$

bSignificantly different from caesarean section, same group; $\mathrm{P}<0.05$.

eicosanoid levels between the ipsilateral and contralateral lungs in $\mathrm{CDH}$ (data not shown). This was not the case, however, and data from both lungs were therefore pooled.

In $\mathrm{CDH}$ pups protein per mg wet lung weight was higher than in controls: $28.8 \pm 0.8 \mu \mathrm{g}$ and $27.5 \pm 1.1 \mu \mathrm{g}$ after caesarean section and spontaneous delivery in $\mathrm{CDH}$, respectively, and 13.5 $\pm 0.1 \mu \mathrm{g}$ and $18.5 \pm 0.6 \mu \mathrm{g}$ in controls, respectively $(P<0.001)$. In controls the protein content per mg lung weight was significantly lower in pups who were delivered by caesarean section than in spontaneously born pups $(P<0.001)$, but this was not true for the total protein content in both lungs $(2020 \pm 9 \mu \mathrm{g}$ after caesarean section and $2060 \pm 24 \mu \mathrm{g}$ after spontaneous birth). In all control pups the total amount of protein was higher than in $\mathrm{CDH}$ pups, whose lungs contained $1760 \pm 12 \mu \mathrm{g}$ and $1710 \pm 8 \mu \mathrm{g}$ protein in the respective groups $(P<0.001)$.

The eicosanoid concentrations per $\mu \mathrm{g}$ protein measured in the lung homogenates are shown in Fig. 1. In controls the concentrations of all eicosanoids per $\mu$ g protein (Fig. 1A-D) and the total amount of eicosanoids (Table 1) were significantly lower in spontaneously born pups, compared with those in the caesarean section group. In $\mathrm{CDH}$ pups the eicosanoid levels were not affected by the delivery mode; this was also the case for the eicosanoid content per mg lung weight (data not shown).

The levels of 6keto-PGF $1 \alpha$ per $\mu \mathrm{g}$ protein (Fig. $1 \mathrm{~A} ; P<0.001$ ) and the total amount of 6 keto-PGF $1 \alpha$ (Table $1 ; P<0.001$ ) were significantly higher in $\mathrm{CDH}$ than in controls. In addition, the ratio of 6-keto- $\mathrm{PGF}_{1 \alpha}$ to $\mathrm{Tx}_{2}$ was calculated for each group; in the caesarean section group it was $0.38 \pm 0.03$ and $0.16 \pm 0.01$ for $\mathrm{CDH}$ and controls, respectively
$(P<0.001)$, and for spontaneously born rat pups $0.39 \pm 0.02$ and $0.16 \pm 0.01$, respectively $(P<0.001)$.

Controls born by caesarean section had higher total $\mathrm{TxB}_{2}$ than $\mathrm{CDH}$ pups (Table $1 ; P=$ $0.006)$ and a tendency towards higher $\mathrm{Tx}_{2}$ per $\mu \mathrm{g}$ protein (Fig. $1 \mathrm{~B} ; P=0.08$ ). No such differences for $\mathrm{TxB}_{2}$ were observed in the spontaneously born rat pups. $\mathrm{PGE}_{2}$ per $\mu$ g protein was significantly higher in control pups delivered by caesarean section than in $\mathrm{CDH}$ pups (Fig. 1C; $P=0.003)$. The total amounts of $\mathrm{PGE}_{2}$ were higher in controls than in $\mathrm{CDH}$ pups, irrespective of the delivery mode (Table 1). The concentration of $\mathrm{LTB}_{4}$ per $\mu$ g protein (Fig. 1D) and the total amount of $\mathrm{LTB}_{4}$ (Table 1) were significantly higher in controls than in $\mathrm{CDH}$ pups after caesarean section $(P<0.001)$, whereas both groups showed similar $\mathrm{LTB}_{4}$ levels after spontaneous delivery.

\section{Eicosanoids in BAL fluid}

In BAL fluid a wide range of eicosanoid concentrations was observed. In controls the concentrations per ml BAL fluid of 6 keto-PGF ${ }_{1 \alpha}, \mathrm{Tx}_{2}$, and $\mathrm{LTB}_{4}$ were higher after spontaneous birth than after caesarean section (Table $2 ; P=0.01$, 0.06 , and $<0.001$, respectively). However, after correction for dilution, with total protein as marker, only $\mathrm{LTB}_{4}$ was significantly higher after spontaneous birth (Table 2; $P=0.02$ ). $\mathrm{CDH}$ pups showed higher uncorrected concentration levels of $\mathrm{TxB}_{2}$ and $\mathrm{LTB}_{4}$ in spontaneously born rats compared with pups delivered by caesarean section (Table $2 ; P=0.04$ and 0.05 , respectively). The same volumes in $\mathrm{CDH}$ pups were so small that the protein concentration could only be measured in eight samples $(n=4$ per group). 
6-keto-PGF ${ }_{1 \alpha}(\mathrm{pg} / \mu \mathrm{g}$ protein)

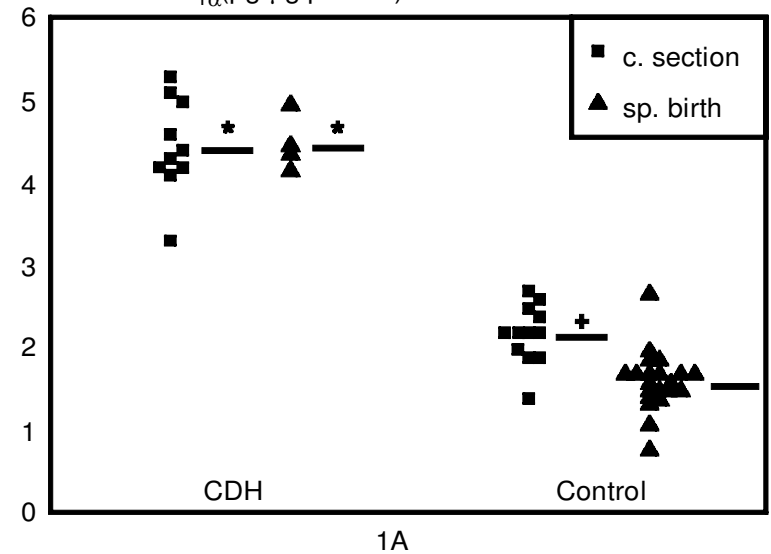

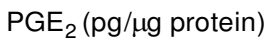

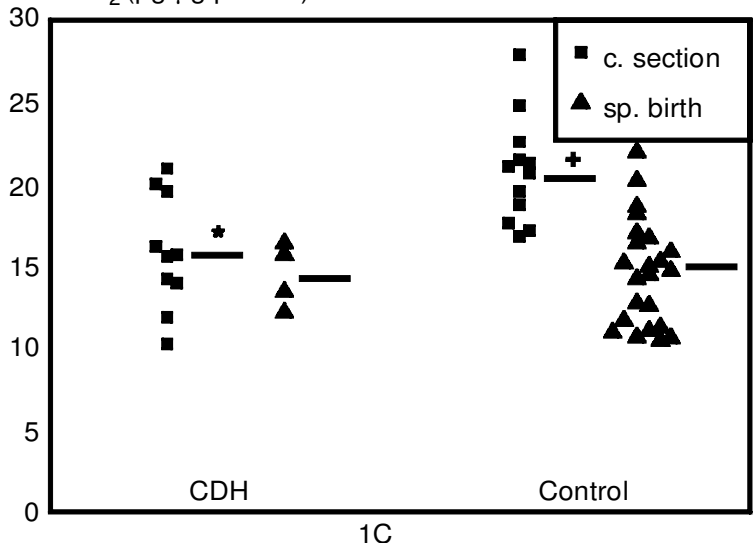

$\mathrm{TxB}_{2}(\mathrm{pg} / \mu \mathrm{g}$ protein)

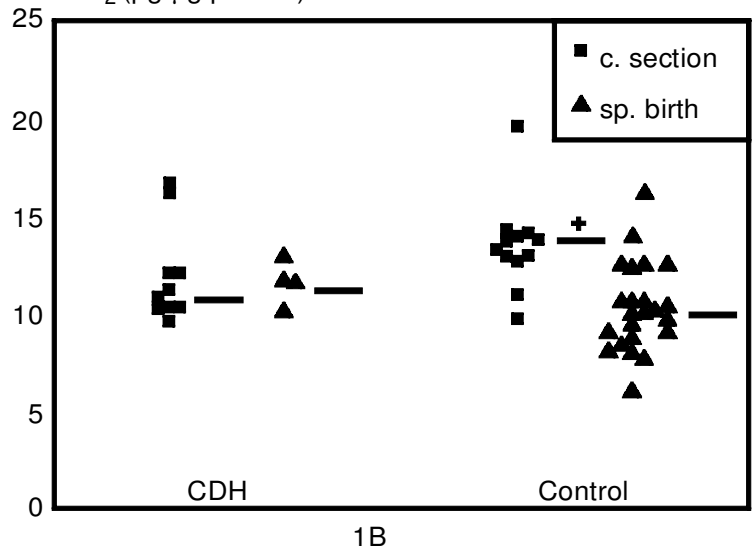

$\mathrm{LTB}_{4}(\mathrm{pg} / \mu \mathrm{g}$ protein)

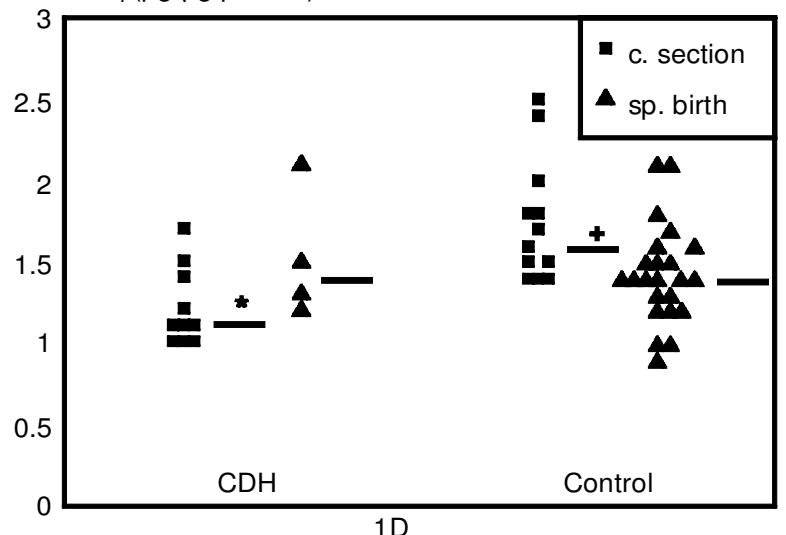

FIG. 1. Concentration of 6-keto-PGF ${ }_{1 \alpha}(1 \mathrm{~A}), \mathrm{TxB}_{2}$ (1B), $\mathrm{PGE}_{2}(1 \mathrm{C})$, and $\mathrm{LTB}_{4}$ (1D) per $\mu \mathrm{g}$ protein in lung homogenates of rat pups with $\mathrm{CDH}$ and controls delivered by caesarean section (squares) or spontaneously born pups (triangles). Median is indicated for each group. *Significantly different from controls; similar mode of delivery; $\mathrm{P}<0.01$. ${ }^{+}$Significantly different from controls after spontaneous birth; $\mathrm{P}<0.02$

Table 2. Eicosanoids in BAL fluid of controls and $\mathrm{CDH}$ pups after delivery by caesarean section or after spontaneous birth

\begin{tabular}{|c|c|c|c|}
\hline & & Caesarean section & Spontaneous birth \\
\hline 6-keto-PGF ${ }_{1 \alpha}(\mathrm{pg} / \mathrm{ml})$ & Control & $171(64-303)$ & $278(102-743)^{\mathrm{a}}$ \\
\hline & $\mathrm{CDH}$ & $207(110-521)$ & $243(172-617)$ \\
\hline 6-keto-PGF ${ }_{1 \alpha}(\mathrm{pg} / \mu \mathrm{g}$ protein) & $\begin{array}{l}\text { Control } \\
\mathrm{CDH}\end{array}$ & $\begin{array}{l}1.72(0.58-14.8) \\
5.53(188-38.9)\end{array}$ & $\begin{array}{l}1.43(1.06-4.04) \\
181(1.12-352)\end{array}$ \\
\hline $\mathrm{TxB}_{2}(\mathrm{pg} / \mathrm{ml})$ & $\begin{array}{l}\text { Control } \\
\mathrm{CDH}\end{array}$ & $\begin{array}{c}100(23-372) \\
65(6-140)\end{array}$ & $\begin{array}{l}182(78-496) \\
96(19-305)^{\mathrm{a}}\end{array}$ \\
\hline 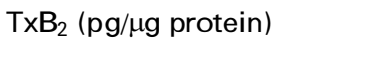 & $\begin{array}{l}\text { Control } \\
\mathrm{CDH}\end{array}$ & $\begin{array}{l}1.19(0.47-5.33) \\
1.62(0.16-6.72)\end{array}$ & $\begin{array}{l}1.18(0.3-2.75) \\
0.69(0.43-2.5)\end{array}$ \\
\hline $\mathrm{LTB}_{4}(\mathrm{pg} / \mathrm{ml})$ & $\begin{array}{l}\text { Control } \\
\mathrm{CDH}\end{array}$ & $\begin{array}{l}15(5-105) \\
42(14-194)\end{array}$ & $\begin{array}{l}162(25-661)^{a} \\
100(51-200)^{a, b}\end{array}$ \\
\hline 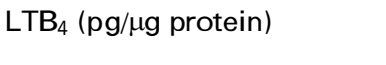 & $\begin{array}{l}\text { Control } \\
\mathrm{CDH}\end{array}$ & $\begin{array}{l}0.24(0.08-6.9) \\
0.23(0.19-2.0)\end{array}$ & $\begin{array}{l}0.92(0.12-2.57)^{a} \\
0.87(0.38-0.99)\end{array}$ \\
\hline
\end{tabular}

All values are expressed as median (range). Data shown per $\mathrm{ml} \mathrm{BAL}$ fluid are $n=10$ for each $\mathrm{CDH}$ group and $\mathrm{n}=13$ per control group. Data shown per $\mu \mathrm{g}$ protein are $\mathrm{n}=4$ for each $\mathrm{CDH}$ group, $n=13$ for controls delivered by caesarean section, and $n=10$ for spontaneously born controls.

aSignificantly different from caesarean section in the same group; $\mathrm{P}<0.05$.

${ }^{b}$ Significantly different from spontaneously born $\mathrm{CDH}$ pups; $\mathrm{P}<0.05$.

The ratio of 6tketo-PGF $1 \alpha$ and $\mathrm{Tx}_{2}$ in $\mathrm{BAL}$ fluid was significantly higher in $\mathrm{CDH}$ pups than in controls who were delivered by caesarean section $(7.93 \pm 2.95$ and $2.22 \pm 0.5$, respec- tively; $P=0.02)$. A similar tendency was observed for the spontaneously born rat pups $(3.63 \pm 1.13$ for $\mathrm{CDH}$, and $1.48 \pm 0.32$ for controls; $P=0.06)$. 


\section{Discussion}

In the present study higher levels of 6-keto-PGF ${ }_{1 \alpha}$, the stable metabolite of the pulmonary vasodilator $\mathrm{PGI}_{2}$, were found in the lungs of $\mathrm{CDH}$ pups than in those of controls, irrespective of the mode of delivery. Lungs of $\mathrm{CDH}$ pups had similar or lower levels of $\mathrm{Tx}_{2}$, $\mathrm{PGE}_{2}$, and $\mathrm{LTB}_{4}$ than control pups. All eicosanoids studied were higher in the lungs of control pups delivered by caesarean section than in those born spontaneously; this was not the case in $\mathrm{CDH}$ pups.

The lower lung weights in spontaneously born controls compared with those delivered by caesarean section probably indicate that lung fluid was absorbed to a large extent during the first adequate breaths. The gasping, irregular breathing movement in the spontaneously born $\mathrm{CDH}$ pups have been insufficient to overcome the pressure that is needed to initiate lung expansion and to provide adequate lung aeration and absorption of lung fluid, ${ }^{26,29}$ thus explaining the similar lung weights in both CDH groups.

We studied the eicosanoid concentration both in lung homogenates and in BAL fluid to determine whether the concentration in BAL fluid adequately reflects the situation in the lung tissue. We found widely varying eicosanoid concentrations in BAL fluid of the neonatal rat pups. After correction for protein, only the concentration of 6-keto-PGF ${ }_{1 \alpha}$ in control pups showed comparable results between BAL fluid and lung homogenates. The concentration of $\mathrm{TxB}_{2}$ was generally 10 times higher in lung homogenates than in BAL fluid, which suggests that thromboxane is mainly present in the pulmonary vasculature and not into the airspaces. The same may be true for the concentration of $\mathrm{LTB}_{4}$ during intrauterine life. Our data support earlier observations that the eicosanoid content in the pulmonary vasculature is more adequately reflected in tissue homogenates than in BAL fluid.7 However, the ratio of 6-keto-PGF $1 \alpha$ and $\mathrm{TxB}_{2}$ was significantly higher in lung homogenates and in BAL fluid of $\mathrm{CDH}$ pups than in that of controls, suggesting that this parameter in BAL fluid reflects the values in lung tissue. A high ratio of 6-keto-PGF $1 \alpha$ and $\mathrm{TxB}_{2}$ was also found in BAL fluid of two $\mathrm{CDH}$ patients with evidence of PPH (unpublished data).

During normal transition from intrauterine to extrauterine life, the pulmonary vascular resistance rapidly declines within the first $30 \mathrm{~s}$, and declines more slowly over the next $10-20 \mathrm{~min}^{2}$ The first phase occurs irrespective of prosta- glandin synthase blockade by indomethacin, ${ }^{2}$ but several studies in lambs and goats indicate that a transient prostacyclin production in the lungs, which is stimulated by tissue stress during establishment of gaseous ventilation and rhythmic ventilation, ${ }^{4}$ is important to sustain further pulmonary vasodilatation within the first hours after birth. ${ }^{2-4,7}$

The lower levels of all eicosanoids in lung tissue of normal controls compared with $\mathrm{CDH}$ pups following spontaneous birth in this study seem to contradict the earlier findings in newborn lambs and goats. ${ }^{2-4,7}$ Perhaps the described loss of prostacyclin from the lungs shortly before birth $^{3}$ continued immediately after birth, and the rat pups died before the prostacyclin concentration began to increase. However, the $\mathrm{CDH}$ pups could not survive much longer without artificial ventilation and supplemental oxygen.

Persistent pulmonary hypertension is a serious problem in neonatology which largely contributes to the neonatal mortality and morbidity in isolated cases of $\mathrm{PPH}^{28}$ and in children with $\mathrm{CDH}^{13}$ Improvement of oxygenation parameters in some children with PPH has been reported after intravenous or inhaled administration of prostacyclin, ${ }^{29,30}$ although other patients seem irresponsive to vasodilator therapy like prostacyclin ${ }^{29}$ or inhaled nitric oxide. $^{28}$

Increased levels of 6keto-PGF $1 \alpha, \mathrm{Tx}_{2}, \mathrm{PGE}_{2}$, and leukotrienes have been reported in plasma and in bronchoalveolar lavage fluid of $\mathrm{PPH}$ patients ${ }^{14,17,19,21}$ and in plasma of $\mathrm{CDH}$ patients with $\mathrm{PPH}^{15,16,21}$ A decrease in all eicosanoid levels was observed during clinical improvement, especially in patients who were being treated with extracorporeal membrane oxygenation. ${ }^{16,21}$ It has been suggested that $\mathrm{LTC}_{4}, \mathrm{LTD}_{4}$ and $\mathrm{Tx}_{2}$ have a pulmonary vasoconstricting activity, whereas 6-keto-PGF $1 \alpha$ opposes the hypoxic vasoconstriction. 31

In a fetal lamb model of chronic intrauterine pulmonary hypertension ${ }^{32}$ increased pulmonary levels of 6-keto-PGF $1 \alpha$ and $\mathrm{TxB}_{2}$ were detected shortly before, and $2 \mathrm{~h}$ after birth. 7 Our study did not reveal significant differences in eicosanoid content in the lungs of the $\mathrm{CDH}$ rats during transition from intrauterine to extrauterine life; this may be due to the short period of survival after birth and the lack of adequate respiratory movements.

We found increased levels of 6-keto-PGF $1 \alpha$ per $\mu \mathrm{g}$ protein, and decreased levels of $\mathrm{PGE}_{2}$ and $\mathrm{LTB}_{4}$ in lung tissue of $\mathrm{CDH}$ pups in the caesarean section group. Surprisingly, the concentration of $\mathrm{Tx}_{2}$ per $\mu$ g protein was similar in 
$\mathrm{CDH}$ pups and in controls. We assumed that a certain total amount of eicosanoids is important to exert a local effect, and we therefore determined the total eicosanoid content in both lungs of $\mathrm{CDH}$ and control pups. The results were similar to the data that were corrected for protein. The increased ratio of 6-keto-PGF $1 \alpha$ and $\mathrm{Tx}_{2}$ in $\mathrm{CDH}$ pups compared with control pups confirms the presence of a dysbalance in vasoactive mediators, which is in favour of the pulmonary vasodilator. It has been suggested that prostaglandin generation in the pulmonary vasculature may reduce the pulmonary vascular pressure response to hypoxia. 31 Cott and coworkers $^{33}$ showed in adult rats that alveolar type II cells are capable of producing high levels of 6-keto-PGF $\mathrm{PG}_{1 \alpha}$ and $\mathrm{PGE}_{2}$ in vitro, whereas $\mathrm{Tx}_{2}$ and $\mathrm{LTB}_{4}$ are mainly produced by alveolar macrophages. Brandsma and coworkers $^{34}$ reported more type II cells that showed retarded differentiation in $\mathrm{CDH}$ lungs. The relatively higher number of type II cells may be responsible for the increased 6keto$\mathrm{PGF}_{1 \alpha}$ content in the $\mathrm{CDH}$ lungs.

In conclusion, the present study shows different eicosanoid profiles in lungs of perinatal rats with and without $\mathrm{CDH}$. The most striking findings are the elevated concentration of 6 keto-PGF ${ }_{1 \alpha}$, and the increased ratio of 6keto$\mathrm{PGF}_{1 \alpha}$ and $\mathrm{TxB}_{2}$ in $\mathrm{CDH}$ lungs. This is the first study of lung eicosanoids in perinatal animals with abnormal lung development. From the present data it is not clear whether the balance which is in favour of 6keto-PGF $1 \alpha$, the stable metabolite of the pulmonary vasodilator $\mathrm{PGI}_{2}$, compensates for an increased pulmonary vascular tone or that it reflects delayed cell differentiation in $\mathrm{CDH}$. Our findings give reason to assume that lungs of $\mathrm{CDH}$ patients with $\mathrm{PPH}$ already contain increased levels of prostacyclin at birth and that the administration of exogenous vasodilators will not be helpful to decrease the pulmonary vascular resistance in those patients.

\section{References}

1. Moncada S, Vane JR. Pharmacology and endogenous roles of prostaglandin endoperoxides, thromboxane $\mathrm{A}_{2}$, and prostacyclin. Pharm acol Rev 1979; 30: 293-331.

2. Leffler CW, Tyler TL, Cassin S. Effect of indomethacin on pulmonary vascular response to ventilation of fetal goats. Am J Physiol 1978; 234: $\mathrm{H} 346-\mathrm{H} 351$.

3. Leffler CW, Hessler JR, Green RS. The onset of breathing at birth stimulates pulmonary vascular prostacyclin synthesis. Pediatr Res 1984; 18: 938-942.

4. Leffler CW, Hessler JR, Green RS. Mechanism of stimulation of pulmonary prostacyclin synthesis at birth. Prostaglandins 1984; 28: $877-887$.

5. Mitchell MD. Prostaglandins during pregnancy and the perinatal period. J Reprod Fert 1981; 62: 305-315.
6. Coceani F, Olley PM. Eicosanoids in the fetal and transitional pulmonary circulation. Chest 1988; 93: 112S-117S.

7. Abman SH, Stenmark KR. Changes in lung eicosanoid content during normal and abnormal transition in perinatal lambs. Am J Physiol 1992; 262: L214-L222.

8. Clyman RI, Mauray F, Roman C, Rudolph AM, Heymann MA. Circulating prostaglandin $\mathrm{E}_{2}$ concentrations and patent ductus arteriosus in fetal and neonatal lambs. J Pediatr 1980; 97: 455-461.

9. Cassin S. Role of prostaglandins, thromboxanes, and leukotrienes in the control of the pulmonary circulation in the fetus and newborn. Sem Perin ato l 1987; 11: 53-63.

10. Cassin S. The role of eicosanoids and endothelium-dependent factors in the regulation of the fetal pulmonary circulation. J Lipid Med 1993; 6: $477-485$.

11. Levin DL Morphologic analysis of the pulmonary vascular bed in congenital left-sided diaphragmatic hernia. J Pediatr 1978; 107: 457-464.

12. George DK, Cooney TP, Chiu BK, Thurlbeck WM. Hypoplasia and immaturity of the terminal lung unit (acinus) in congenital diaphragmatic hernia. Am Rev Respir Dis 1987; 136: 947-950.

13. Molenaar JC, Bos AP, Hazebroek FWJ, Tibboel D. Congenital diaphragmatic hernia, what defect? J Pediatr Surg 1991; 26: 248-254.

14. Stenmark KR, James SL, Voelkel NF, Toews WH, Reeves JT, Murphy RC Leukotriene $\mathrm{C}_{4}$ and $\mathrm{D}_{4}$ in neonates with hypoxemia and pulmonary hypertension. NEngl J Med 1983; 309: 77-80.

15. Ford WDA, James MJ, Walsh JA. Congenital diaphragmatic hernia: association between congenital pulmonary vascular resistance and plasma thromboxane concentrations. Arch Dis Child 1984; 59: $143-146$.

16. Stolar CJH, Dillon PW, Stalcup SA. Extracorporeal membrane oxygenation and congenital diaphragmatic hernia: modification of the pulmonary vasoactive profile. J Pediatr Surg 1985; 20: 681-683.

17. Hammerman C, Lass N, Strates E, Komar K, Bui KC. Prostanoids in neonates with persistent pulmonary hypertension. J Pediatr 1987; 110: $470-472$.

18. Bos AP, Tibboel D, Hazebroek FWJ, Stijnen T, Molenaar JC. Congenital diaphragmatic hernia: impact of prostanoids in the perioperative period. Arch Dis Child 1990; 65: 994-995.

19. Bui KC, Hammerman C, Hirschl RB, Snedecor SM, Cheng KJ, Chan I, Short BL, Bartlett RH. Plasma prostanoids in neonates with pulmonary hypertension treated with conventional therapy and with extracorporeal membrane oxygenation. J Thorac Cardiovasc Surg 1991; 101: 973-983.

20. Nakayama DK, Motoyama EK, Evans R, Hannakan C. Relation between arterial hypoxemia and plasma eicosanoids in neonates with congenital diaphragmatic hernia. J Surg Res 1992; 53: 615-620.

21. Dobyns EL, Westcott JY, Kennaugh JM, Ross MN, Stenmark KR. Eicosanoids decrease with successful extracorporeal membrane oxygenation therapy in neonatal pulmonary hypertension. Am J Respir Crit Care Med 1994; 149: 873-880.

22. Kluth D, Kangah R, Reich P, Tenbrinck R, Tibboel D, Lambrecht W. Nitrofen-induced diaphragmatic hernias in rats: an animal model. J Pediatr Surg 1990; 25: 850-854.

23. Tenbrinck R, Gaillard JLJ, Tibboel D, Kluth D, Lachmann B, Molenaar JC. Pulmonary vascular abnormalities in experimentally induced congenital diaphragmatic hernia in rats. J Pediatr Surg 1990; 27: $862-865$.

24. Brandsma AE, Tibboel D, Vulto IM, Egberts J, Ten Have-Opbroek AAW. Ultrastructural features of alveolar epithelial cells in the late fetal pulmonary acinus: a comparison between normal and hypoplastic lungs using a rat model of pulmonary hypoplasia and congenital diaphragmatic hernia. Micr Res Techn 1993; 26: 389-399.

25. Zijlstra FJ, Vincent JE, Mol WM, Hoogsteden HC, Van Hal PThW. Eicosanoid levels in bronchoalveolar lavage fluid of young female smokers and non-smokers. Eur J Clin Invest 1992; 22: 301-306.

26. Agostini E, Taglietti A, Agostini F, Setnikar I. Mechanical aspects of the first breath. JAppl Physiol 1958; 13: 344-348.

27. Tenbrinck R, Scheffers EC, IJsselstijn H, Tibboel D, Lachmann B. Nitrofen induced diaphragmatic hernia: pressure-volume registration and artificial ventilation in newborn rats. Applied Cardiopulmonary Pathophysiology 1995; 5: 257-264.

28. Steinhorn RH, Millard SL, Morin III FC. Persistent pulmonary hypertension of the newborn. Role of nitric oxide and endothelin in pathophysiology and treatment. Clin Perin atol 1995; 22: 405-427.

29. Bos AP, Tibboel D, Koot VCM, Hazebroek FWJ, Molenaar JC. Persistent pulmonary hypertension in high-risk congenital diaphragmatic hernia patients: incidence and vasodilator therapy. J Pediatr Surg 1993; 28: $1463-1465$.

30. Bindl L, Fahnenstich H, Peukert U. Aerosolised prostacyclin for pulmonary hypertension in neonates. Arch Dis Child 1994; 71: F214-F216.

31. Weir EK, McMurthy IF, Tucker A, Reeves JT, Grover RF. Prostaglandin synthetase inhibitors do not decrease hypoxic pulmonary vasoconstriction. JAppl Physiol 1976; 41: 714-718.

32. Abman SH, Shanley PF, Accurso FJ. Failure of postnatal adaptation of the pulmonary circulation after chronic intrauterine pulmonary hyper- 
tension in fetal lambs. J Clin Invest 1989; 83: 1849-1858.

33. Cott GR, Westcott JY, Voelkel NF. Prostaglandin and leukotriene production by alveolar type II cells in vitro. Am J Physiol 1990; 258 L179-L187.

34. Brandsma AE, Ten Have-Opbroek AAW, Vulto IM, Molenaar JC, Tibboel D. Alveolar epithelial composition and architecture of the late fetal pulmonary acinus: an immunohistochemical and morphometric study in a rat model of pulmonary hypoplasia and congenital diaphragmatic hernia. Exp Lung Res 1994; 20: 491-515.
ACKNOWLEDGEMENTS. The authors want to thank M. van Aken (Center for Animal Research, Erasmus University Rotterdam) for excellent technical assistance. This work was financially supported by the Netherlands Asthma Foundation, project number 91.56 .

\section{Received 23 October 1996; accepted 26 November 1996}




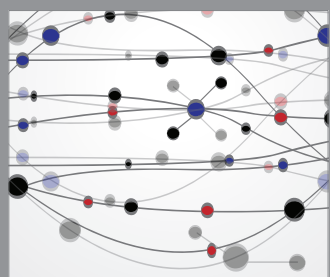

The Scientific World Journal
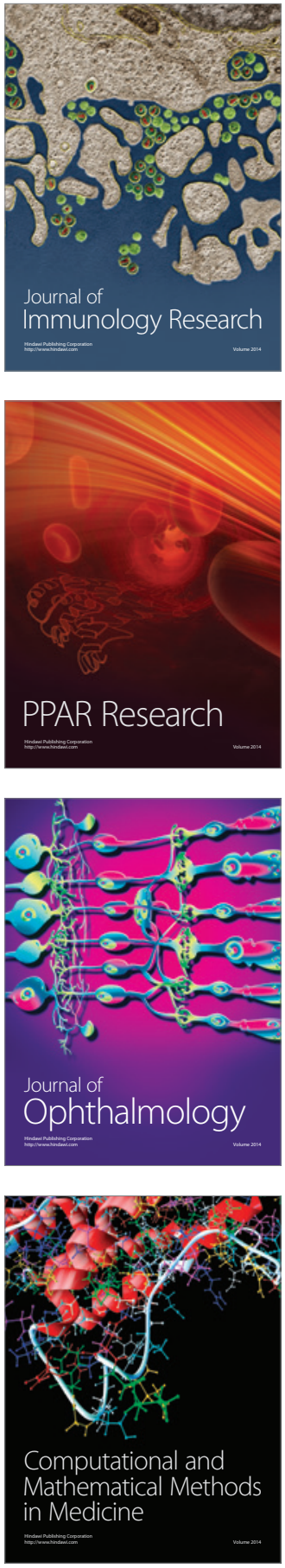

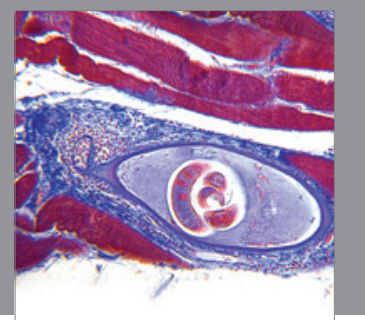

Gastroenterology

Research and Practice
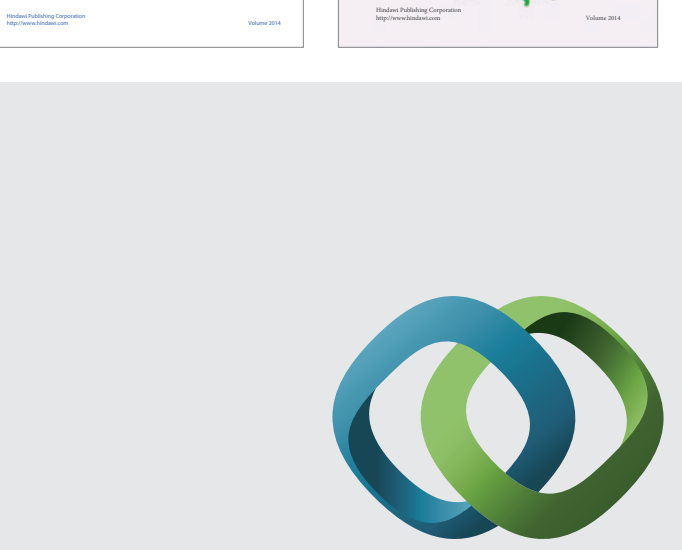

\section{Hindawi}

Submit your manuscripts at

http://www.hindawi.com
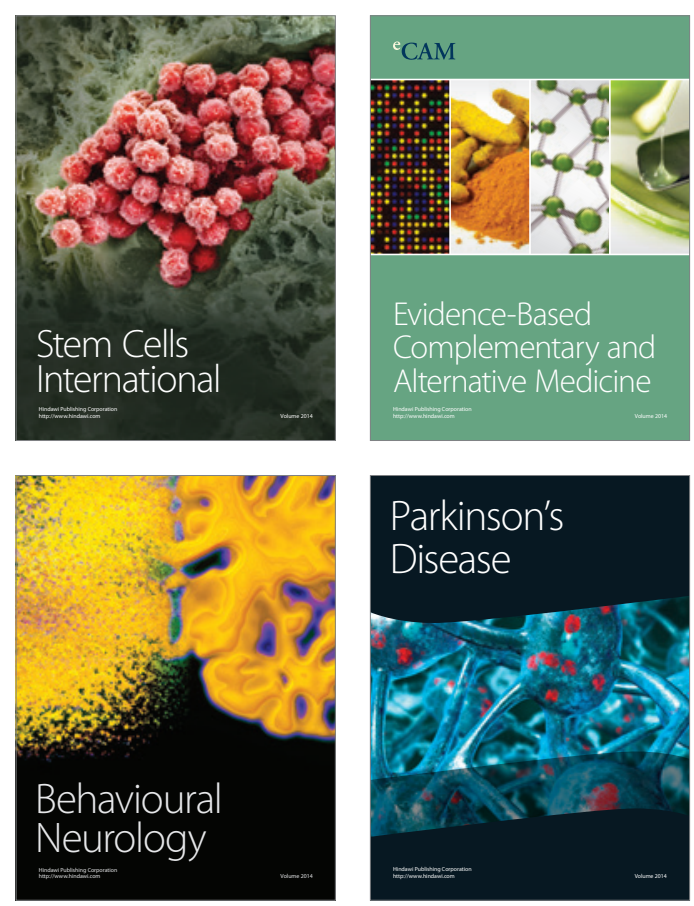

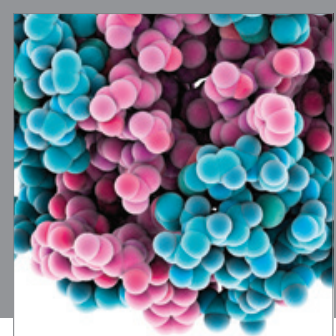

Journal of
Diabetes Research

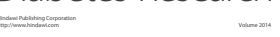

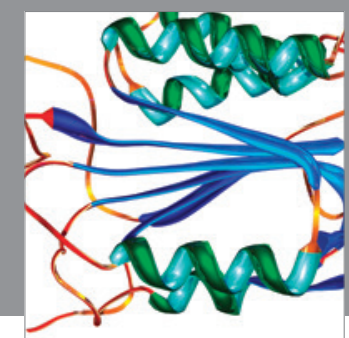

Disease Markers
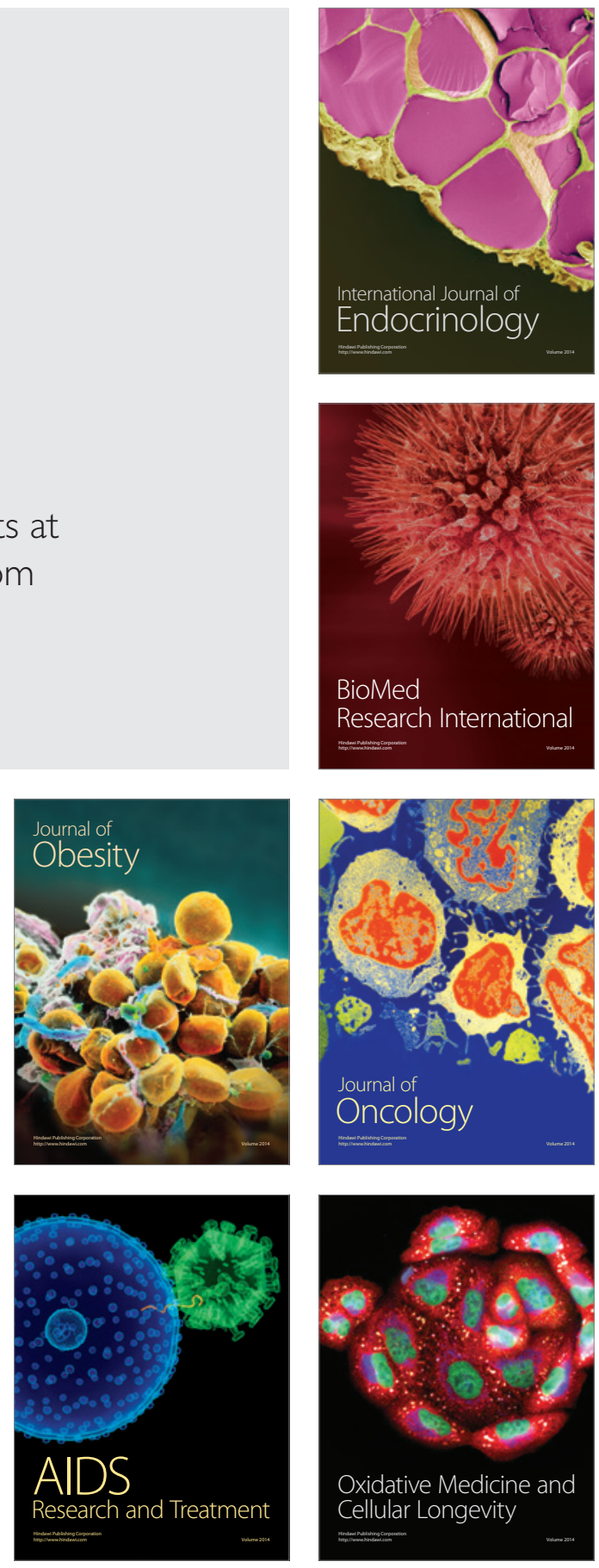